\title{
A Study of Morphological and Morphometric Variations in Sri Lankan Femoral Diaphysial Nutrient Foramina
}

\author{
Estudio de las Variaciones Morfológicas y Morfométricas de \\ los Forámenes Nutricios Diafisarios de Fémur en Sri Lanka
}

Lanka Ranaweera $^{1}$; Perera, P. I. $^{2}$; Pathiraja, P. P. M. C. K. ${ }^{2}$; Sulani, W. N. ${ }^{2}$ \& Wijesooriya, W. A. P. S. ${ }^{2}$

RANAWEERA, L.; PERERA, P. I.; PATHIRAJA, P. P. M. C. K.; SULANI, W. N. \& WIJESOORIYA, W. A. P. S. Study of morphological and morphometric variations in Sri Lankan femoral diaphysial nutrient foramina. Int. J. Morphol., 38(5):1311-1316, 2020.

SUMMARY: Blood supply to the diaphysis of long bones is majorly through nutrient artery, which enters the bone via nutrient foramen. The present study aims to identify morphological and morphometric variations of nutrient foramina of the femur, which is the largest long bone of the body extending from the pelvis to knee. A sample of 81 Sri Lankan adult femur were analyzed. The mean length of the femur analyzed was $436.93 \mathrm{~mm}$ and mean foramen index was 43.52 . The majority of the bones had a single nutrient foramen. The predominant location of the nutrient foramen was on the posterior aspect of the bone in the middle third of the shaft according to the study. Majority of foramina were directed distally. The indices on nutrient foramen are important for procedures such as bone grafts and tumor resections, in managing trauma, orthopedic procedures and radiological interpretations.

KEY WORDS: Femur; Nutrient foramina; Morphology; Morphometric variations.

\section{INTRODUCTION}

Femur is the long bone in the human thigh, which extends from the pelvis to the knee. It is the longest and strongest bone in the body. It is a part of the appendicular skeleton, which consists of a diaphysis and two ends known as epiphyses.

A typical long bone is supplied by four types of arterial systems; named nutrial, epiphyseal, diaphysial and periosteal arteries. The structures such as periosteum, the outer one-third of the underlying cortex and surrounding muscles are supplied by periosteal circulation. The bone marrow and inner two-third of the cortex are supplied by the medullary circulation, which originates from the nutrient arteries. It gives branches within the marrow cavity towards each end of the diaphyseal bone (Sevitt \& Thompson, 1965; Shapiro, 2008). There are considerable intracortical anastomoses between the inner medullary and outer periosteal vessels (Trueta \& Morgan, 1960; Rhinelander, 1968). During childhood, long bones receive about $80 \%$ of the interosseous blood supply from the nutrient arteries, and vascularization occurs through the periosteal vessels in the case of their absence (Trueta \& Harrison, 1953).
The nutrient artery of the femur usually arises from the perforating branches of the profunda femoris artery or less commonly directly from the profunda femoris artery. Rarely the nutrient artery may arise from the lower segments of the femoral artery. In addition to the nutrient artery femur gets its blood supply via the artery of the ligamentum teres and retinacular arteries.

Femur is a highly vascular structure, which receives its blood supply through numerous foramina located over its different segments which are named as vascular foramina. Among those vascular foramina nutrient foramen is the most important one which gives way to the neurovascular bundle. Nutrient foramen is marked by a slight ridge at its commencement and a groove for the nutrient artery throughout its course. There is a correlation in between the direction of the canal with ossification and growth of the bone. Initially nutrient canal is horizontal and gets slanted during growth. Direction of slant is a result of the difference in growth rates of both sides of epiphysis. Variations in the direction of the nutrient foramina are only reported in the lower limb bones (Longia et al., 1980). However, variations 
in the direction of nutrient foramina in long bones of the upper limb have never been reported.

Nutrient foramina reflect to a certain degree the bone vascularization. Disruption of nutrient artery in growing bone can result in necrosis of a large portion of marrow and inner two thirds of the cortex. Therefore, it is important to preserve the arterial supply in free vascularized bone grafts so that osteocytes and osteoblasts survive (Gümüsburun et al. 1994). Some pathological bone conditions such as developmental abnormalities, fracture healing or acute haematogenic osteomyelitis are closely related to the vascular system of the bone. According to Mysorekar (1967), diaphysial nutrient foramina of long bones usually follow a definite pattern. Therefore, the knowledge on variation of diaphysial nutrient foramina can be crucial in various clinical procedures as discussed above.

In Sri Lanka, still there is a need for analysis of the nutrient foramina of femur as it has not been studied previously. The study is aimed to analyze the variations in number, location and the direction of the nutrient foramen using the femur obtained from the Sri Lankan subjects.

\section{MATERIAL AND METHOD}

The study was done on 81 femur obtained from Osteology Laboratory of Department of Anatomy and Museum of Forensic Medicine at the Faculty of Medicine, University of Kelaniya and Department of Anatomy, Gampaha Wickramarachchi Ayurveda Institute, Yakkala. All the bones were adult femur of Sri Lankan origin. The bones were conformed as adult by observing for epiphyseal lines. Bones were observed for pathological defects and such femur were excluded. Nutrient foramina were located by macroscopic observation and confirmed by observing through a hand lens. The nutrient foramina were identified by the well-defined, elevated margin and distinct groove running towards the foramen. The direction and the location of the foramen was noted. Foramina within $1 \mathrm{~mm}$ from a margin of the bone shaft was considered as located on the margin. In bones with more than one nutrient foramen, the largest one was considered as the major nutrient foramen. The patency of each nutrient foramen was confirmed by inserting a gauge 24 steel hypodermic needle into the foramina (Fig. 1).

Diameter of the major nutrient foramen was estimated using steel hypodermic needles of known gauge. The steel hypodermic needles were inserted into the major nutrient foramen, starting from the needle with least cross-sectional

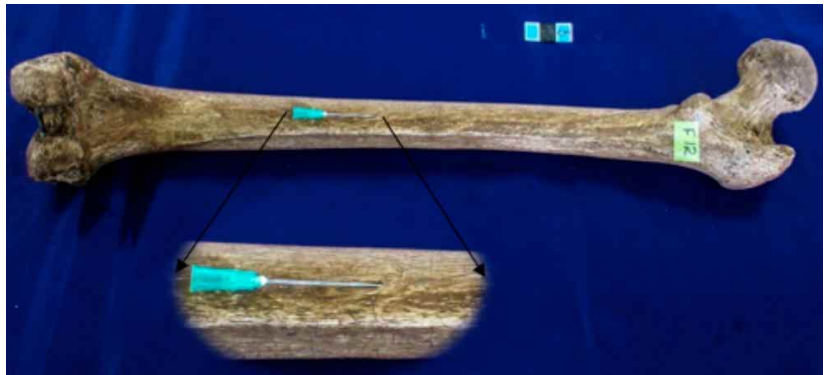

Fig.1. A Femur ready to be analyzed with the nutrient foramen marked using a gauge 24 steel hypodermic needle.

diameter (gauge 24), to find out the needle with maximum cross-sectional diameter that can be accommodated within the foramen. The diameter of the major nutrient foramen was estimated using the outer diameter of the bore of the largest steel hypodermic needle that accommodated into the foramen (Poornima \& Angadi, 2015). Needles of gauge 24 $(0.57 \mathrm{~mm}), 22(0.72 \mathrm{~mm}), 20(0.91 \mathrm{~mm})$ and $18(1.27 \mathrm{~mm})$ were used in this study (Sigma-Aldrich, 2017).

The major nutrient foramen was marked by tying a thread around the shaft at the location of the foramen. The length of the femur and the distance from the major foramen to the proximal end of the femur were measured using a standard measuring tape graduated in centimeters and millimeters and two $15 \mathrm{~cm}$ rulers (Fig. 2). The linear distance from the proximal end of the head of the femur to the most distal point on the medial epicondyle of the femur was considered as the length of the femur.

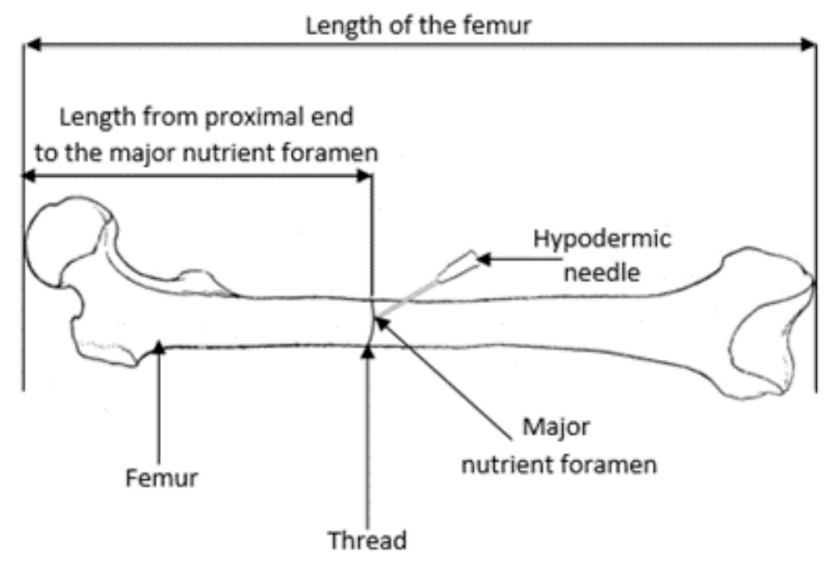

Fig. 2. Measurements used to calculate the foramen index.

Nutrient foramen index was calculated using Hughes formula (Hughes, 1952; Shulman, 1959). (Formula 1)

\footnotetext{
Distance from the proximal end of the femur to

Foramen index $=\frac{\text { the major nutrient foramen }}{\text { Length of the femur }} \times 100$
} 
The linear distribution of the major nutrient foramen on shaft of femur was classified using the foramen index described by Kumar et al. (2013). The foramen index range and the linear location of the major nutrient foramen on the shaft of femur according to the above classification are indicated in the Table I below.

All the bones were photographed against a uniform background, with the nutrient foramen marked by a steel hypodermic needle, using a Canon EOS 500D digital camera. All the data were collected and analyzed using Microsoft Office Access 2016.

Table I. Type of foramen index according to classification by Kumar et al. (2013).

\begin{tabular}{cccl}
\hline Type & $\begin{array}{c}\text { Foramen Index Range } \\
\text { Minimum }\end{array}$ & Maximum & Location on Shaft of femur \\
\hline 1 & 0 & 33.33 & proximal third of the bone \\
2 & 33.34 & 66.66 & middle third of the bone \\
3 & 66.67 & 100 & distal third of the bone \\
\hline
\end{tabular}

\section{RESULTS}

The length of the femur varied between $369 \mathrm{~mm}$ to $557 \mathrm{~mm}$ among the analyzed 81 femur. Average length of the femur was $436.93 \mathrm{~mm}$.

Number of nutrient foramina. Out of femur analyzed in the current study, 47 (58\%) had one nutrient foramen, 29 (36\%) had two nutrient foramina and $5(6 \%)$ had three nutrient foramina. No femur were found to be with absent nutrient foramina.

Location of major nutrient foramina. The major nutrient foramina were observed to be distributed mainly among four specific regions of the shaft of femur; lateral lip of linea aspera (LA), medial lip of linea aspera, on linea aspera and on medial surface. As indicated in Figure 3 below, location of the major nutrient foramina varied as, $38 \%$ (31) on linea aspera, $32 \%$ (26) on medial lip of linea aspera, $14 \%$ (11) on lateral lip of linea aspera, $16 \%$ (13) on medial surface of the bone and $0 \%$ on lateral surface.

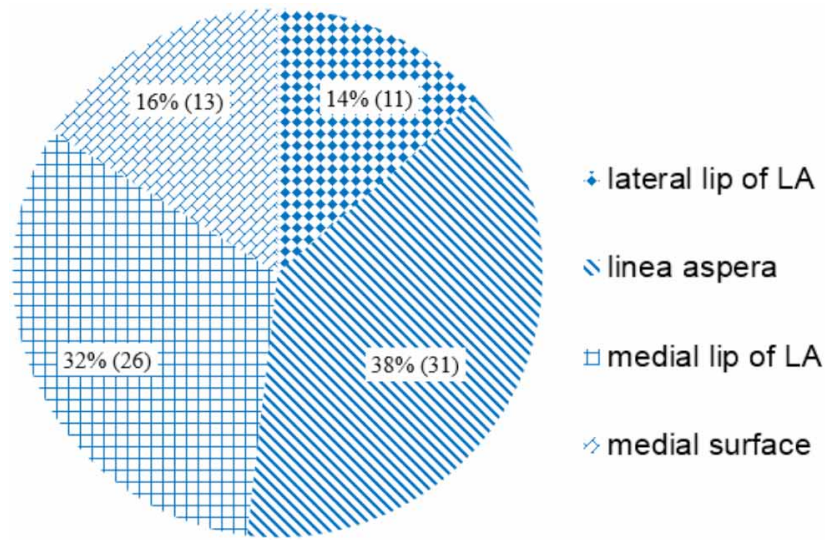

Fig. 3 Location of major nutrient foramen on shaft of femur.

Foramen index. The foramen index varied from 29.61 to 61.73. Mean foramen index was 43.52. According to foramen index types (Kumar et al.);

- Type 1 - $15 \%$ (12) had the nutrient foramen in the proximal third of the shaft (foramen index less than 33.33).

- Type 2 - $85 \%$ (69) had the nutrient foramen in the middle third of the shaft (foramen index between 33.3 and 66.6).

- Type 3 - No nutrient foramina were observed on the distal one third of the shaft (foramen index greater than 66.6).

Commonest location of the nutrient foramen was found to be on the linea aspera at middle third of the shaft, which was 24 out of the 81 femur according to our study. The distribution of nutrient foramina is indicated in the following bar chart (Fig. 4).

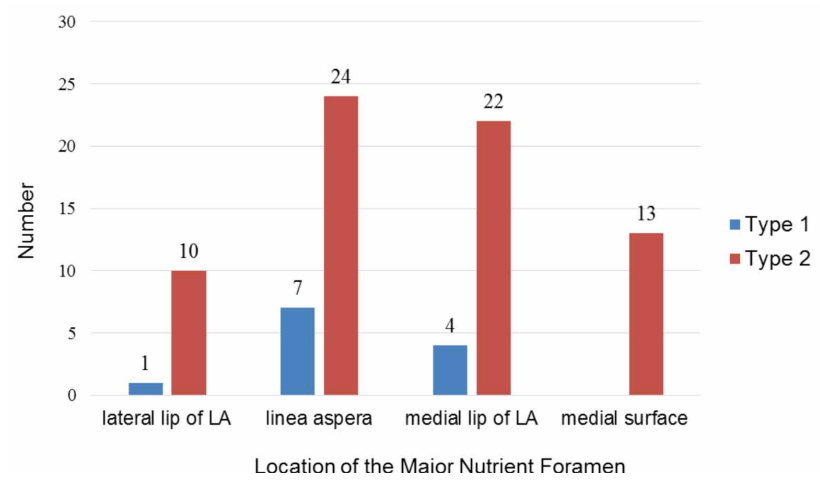

Fig. 4 Location and type of nutrient foramen distribution of femur.

Table II. The measurements of the nutrient foramina estimated by the gauge of the largest steel hypodermic needle accommodated into the foramen.

\begin{tabular}{lcccc}
\hline Needle gauge & $\begin{array}{c}\text { External diameter of the } \\
\text { needle }\end{array}$ & $\begin{array}{c}\text { Estimated diameter of the nutrient } \\
\text { foramen }\end{array}$ & $\begin{array}{c}\text { Results } \\
\text { Number of foramina }\end{array}$ & \begin{tabular}{c} 
Percentage \\
\hline 18
\end{tabular} \\
$1.27 \mathrm{~mm}$ & $>=1.27 \mathrm{~mm}$ & 36 & $28 \%$ \\
20 & $0.91 \mathrm{~mm}$ & $0.91 \mathrm{~mm}$ to $1.26 \mathrm{~mm}$ & 10 & $44 \%$ \\
22 & $0.72 \mathrm{~mm}$ & $0.72 \mathrm{~mm}$ to $0.90 \mathrm{~mm}$ & 12 & $12 \%$ \\
24 & $0.57 \mathrm{~mm}$ & $0.57 \mathrm{~mm}$ to $0.71 \mathrm{~mm}$ & $15 \%$ \\
\hline
\end{tabular}


Diameter and direction of major nutrient foramina. The diameter of major nutrient foramina was estimated using steel hypodermic needles of known bore sizes (gauge). Most of the foramina (44\%) were between $0.91 \mathrm{~mm}$ and 1.62 $\mathrm{mm}$ diameter range according to our findings. The results obtained are shown in Table II.

Regarding the direction of the nutrient foramen, out of the 81 femur only 1 (1.33\%) had the nutrient foramen directed to the distal end.

\section{DISCUSSION}

The average length of the femur of the current study $(436.93 \mathrm{~mm}$ ) fitted with the results of Pereira et al. (2011) and Gümüsburun et al. The mean foramen index of 43.52 of the study tallied with findings of Brazilian adults which was 43.7 (Pereira et al.). Variation of foramen index between 29.61 and 61.73 , and $85 \%$ of the nutrient foramina being located in the middle third of the femur as found in present study were in accordance with many studies, where foramen index was reported to vary between 25 and 75 , thus the nutrient foramina mostly occupying the middle third of the femur (Mysorekar; Forriol Campos et al., 1987; Sendermir \& Cimen, 1991; Kizilkanat et al., 2007; Murlimanju et al., 2011; Mazengenya \& Fasemore, 2015).

Majority of the current results showing presence of a single nutrient foramen (58\%) was in agreement with South African Black population $(64.4 \%$ ) (Mazengenya \& Fasemore), studies done at Punjab Institute of Medical Sciences (54\%) by Sharma et al. (2015) and studies by Murlimanju et al. which was $47.7 \%$. Interestingly, Brazilian population revealed a majority of the samples with a single nutrient foramen with the high occurrence of $90.8 \%$ (Pereira et al.) of the analyzed samples, thus not in accordance with our results. This differs from the findings of White South Africans where $52.2 \%$ of the bones had two nutrient foramina (Mazengenya \& Fasemore) and in Rohilkhand region where $68 \%$ of the bones had two nutrient foramina (Kumar et al.), whereas the current study revealed only 36 $\%$ of the femur with two nutrient foramina. Although Gümüsburun et al. and Forriol Campos et al. reported approximately $10 \%$ of the femur, Murlimanju et al. reported $3.5 \%$ of the femur and Pereira et al. reported $1.28 \%$ of the femur to possess 3 nutrient foramina, our study revealed 6 $\%$ of the femur to possess 3 nutrient foramina. Similar to studies done at Brazil by Pereira et al., none were found with absent nutrient foramina in the current study. However, Kumar et al. reported two femur with absent foramina and Mazengenya \& Fasemore reported a femur with absent nutrient foramina in South African Black adults. Moreover, Sharma et al. reported 1 in 50 femurs to be of absent nutrient foramina and Murlimanju et al. reported $4.6 \%$ of the femurs without nutrient foramina whereas Gümüsburun et al. reported that $1.9 \%$ of the femur to be of absent nutrient foramina. These results were not according to the findings of the current study. Interestingly, Sendermir \& Cimen reported femur with 8 to 9 nutrient foramina whereas Gümüsburun et al. reported femur with 4 to 6 nutrient foramina. In the current study no femur was found to have more than 3 nutrient foramina. The number of nutrient artery is one of the important factors considered in the case of graft surgeries. A graft with good vascular supply will have better results. Therefore, the anatomical details of the nutrient foramina are really essential for the clinician who is involved in vascular graft procedures as well as in microsurgical vascularized bone transplantation. In the absence of nutrient foramen, the bone is likely to be supplied by periosteal arteries. In such cases, delayed healing or nonunion fracture may occur in middle or lower diaphysis of long bones following trauma.

In the present study, majority of nutrient foramina $(38 \%)$ were found to be located on linea aspera which is in accordance with findings of Sendermir \& Cimen, Kizilkanat et al., Murlimanju et al. and Collipal et al. (2007). But a Korean study revealed that majority of the nutrient foramina $(58.9 \%)$ were located on the medial lip of linea aspera (Lee et al., 1994). Interestingly, $84 \%$ of the foramina of the study were on the posterior side of the femur, which was similar to results obtained by Mazengenya \& Fasemore in South African Black population (82.7 \%) and in South African White population $(79.2 \%)$. An accurate knowledge on location of nutrient foramina is necessary in order to prevent intraoperative injuries during orthopedic, plastic or reconstructive surgical procedures.

Diameter of majority of foramina $(44 \%)$ of the present study were estimated to be between $1.26 \mathrm{~mm}$ to 0.91 $\mathrm{mm}$ (admitted gauge 20 needle), which was comparable to results from Karnataka, India where diameter of majority of nutrient foramina $(64.7 \%)$ of femur were estimated to be between $1.26 \mathrm{~mm}$ and $0.91 \mathrm{~mm}$ (Poornima \& Angadi). However, $28 \%$ of nutrient foramina were estimated to have a diameter greater than or equal to $1.26 \mathrm{~mm}$ whereas the previously mentioned Karnataka study indicated $7.2 \%$. Moreover, $15 \%$ of nutrient foramina were less than or equal to $0.57 \mathrm{~mm}$ in diameter, which was $11.5 \%$ in Karnataka (Poornima \& Angadi).

Regarding the nutrient foramen direction, out of the 81 femur analyzed $80(98.8 \%)$ had the nutrient foramen directed distally. It is similar to findings of Mazengenya \& 
Fasemore which showed nutrient foramens of $99.4 \%$ in blacks and $98.8 \%$ in whites of South African population. Kumar et al. showed 148 distally directed nutrient foramina out of the 150 femur analyzed $(98.7 \%)$. The direction of nutrient foramen is determined by the unequal growth rates of the two diaphysial ends of the bone, during developmental stages (Mysorekar). The growing end is supposed to grow at least twice as fast as the other end. The nutrient artery passes opposite direction to the growing end because of the growing part might pull and disrupt the arterial circulation. Therefore, the nutrient foramina are directed away from the growing end.

\section{CONCLUSION}

This novel study of Sri Lankan femur indicates that the nutrient foramen of femur is commonly distributed in the posterior aspect of the middle third of the shaft and is directed distally. Majority of femur had only one nutrient foramen. The information related to the anatomical characteristics of nutrient foramina is vital to preserve the blood circulation of affected bony structures during the surgical procedures such as bone graft, microvascular bone surgery and bone repair.

\section{ACKNOWLEDGMENTS}

We would like to express our sincere gratitude to all the technical and non-academic staff of the Department of Anatomy and Department of Forensic Medicine at the Faculty of Medicine, University of Kelaniya and Department of Anatomy, Gampaha Wickramarachchi Ayurveda Institute, Yakkala for their constant help and cooperation towards this research work.

RANAWEERA, L.; PERERA, P. I.; PATHIRAJA, P. P. M. C. K.; SULANI, W. N. \& WIJESOORIYA, W. A. P. S. Estudio de las variaciones morfológicas y morfométricas de los forámenes nutricios diafisarios de fémur en Sri Lanka. Int. J. Morphol., 38(5):1311-1316, 2020.

RESUMEN: El suministro de sangre a la diáfisis de los huesos largos se realiza principalmente a través de la arteria nutricia, que ingresa al hueso a través del foramen nutricio diafisario. El presente estudio tiene como objetivo identificar las variaciones morfológicas y morfométricas del foramen nutricio del fémur, el hueso largo más grande del cuerpo que se extiende desde la pelvis hasta la rodilla. Se analizó una muestra de 81 fémures adultos de individuos de Sri Lanka. La longitud media de los fémures analizados fue de 436,93 mm y el índice de foramen medio fue de 43,52.
La mayoría de los huesos tenían un solo foramen nutricio. Según el estudio, la ubicación predominante del foramen nutricio estaba en la cara posterior del hueso en el tercio medio del eje. La mayoría de los forámenes estaban dirigidos distalmente. Los índices sobre el foramen nutricio son importantes para procedimientos tales como injertos óseos y resecciones tumorales, en el manejo de traumatismos, procedimientos ortopédicos e interpretaciones radiológicas.

PALABRAS CLAVE: Fémur; Foramen nutricio; Morfología; Variaciones morfométricas.

\section{REFERENCES}

Collipal, E.; Vargas, R.; Parra, X.; Silva, H. \& del Sol, M. Diaphyseal nutrient foramina in the femur, tibia and fibula bones. Int. J. Morphol., 25(2):305-8, 2007.

Forriol Campos, F.; Gomez Pellico, L.; Gianonatti Alias, M. \& Fernandez-Valencia, R. A study of the nutrient foramina in human long bones. Surg. Radiol. Anat., 9(3):251-5, 1987.

Gümüsburun, E.; Yücel, F.; Ozkan, Y. \& Akgün, Z. A study of the nutrient foramina of lower limb long bones. Surg. Radiol. Anat., 16(4):409$12,1994$.

Hughes, H. The factors determining the direction of the canal for the nutrient artery in the long bones of mammals and birds. Acta Anat (Basel), 15(3):261-80, 1952.

Kizilkanat, E.; Boyan, N.; Ozsahin, E. T.; Soames, R. \& Oguz, O. Location, number and clinical significance of nutrient foramina in human long bones. Ann. Anat., 189(1):87-95, 2007.

Kumar, R.; Mandloi, R. S.; Singh, A. K.; Kumar, D. \& Mahato, P. Analytical and morphometric study of nutrient foramina of femur in Rohilkhand region. IJMHS, 3(2):2013. Available from: https:// www.semanticscholar.org/paper/ANALYTICAL-ANDMORPHOMETRIC-STUDY-OF-NUTRIENT-OF-IN-KumarMandloi/b6979b251eabf912c73b4723aeb58d995e7e089e

Lee, H. Y.; Kim, H. S.; Suh, J. S. \& Chung, I. H. A metric study of the femoral, tibial and fibular nutrient foramens in Korean adults. Korean J. Phys. Anthropol., 7(1):125-36, 1994.

Longia, G. S.; Ajmani, M. L.; Saxena, S. K. \& Thomas, R. J. Study of diaphyseal nutrient foramina in human long bones. Acta Anat (Basel), 107(4):399-406, 1980.

Mazengenya, P. \& Fasemore, M. D. Morphometric studies of the nutrient foramen in lower limb long bones of adult black and white South Africans. Eur. J. Anat., 19(2):155-63, 2015.

Murlimanju, B. V.; Prashanth, K. U.; Prabhu, L. V.; Chettiar, G. K.; Pai, M. M. \& Dhananjaya, K. V. N. Morphological and topographical anatomy of nutrient foramina in the lower limb long bones and its clinical importance. Australas. Med. J., 4(10):530-7, 2011.

Mysorekar, V. R. Diaphysial nutrient foramina in human long bones. $J$. Anat., 101(4):813-22, 1967.

Pereira, G. A. M.; Lopes, P. T. C.; Santos, A. M. P. V. \& Silveira, F. H. S. Nutrient foramina in the upper and lower limb long bones: morphometric study in bones of Southern Brazilian adults. Int. J. Morphol., 29(2):514-20, 2011.

Poornima, B. \& Angadi, A. V. A study of nutrient foramina of the dry adult human femur bones. Int. J. Biomed. Res., 6(6):370-3, 2015.

Rhinelander, F. W. The normal microcirculation of diaphyseal cortex and its response to fracture. J. Bone Joint Surg. Am., 50(4):784-800, 1968.

Sendermir, E. \& Cimen, A. Nutrient foramina in the shafts of lower limb long bones: situation and number. Surg. Radiol. Anat., 13(2):105-8, 1991. 
RANWAEERA, L.; PERERA, P. I.; PATHIRAJA, P. P. M. C. K.; SULANI, W. N. \& WIJESOORIYA, W. A. P. S. Study of morphological and morphometric variations in Sri Lankan femoral diaphysial nutrient foramina. Int. J. Morphol., 38(5):1311-1316, 2020.

Sevitt, S. \& Thompson, R. G. The distribution and anastomoses of arteries supplying the head and neck of the femur. J. Bone Joint Surg. Br., 47:560-73, 1965

Shapiro, F. Bone development and its relation to fracture repair. The role of mesenchymal osteoblasts and surface osteoblasts. Eur. Cell Mater., 15:53-76, 2008.

Sharma, M.; Prashar, R.; Sharma, T.; Wadhwa, A. \& Kaur, J. Morphological variations of nutrient foramina in lower limb long bones. Int. J. Med. Dent. Sci., 4(2):802-8, 2015.

Shulman, S. S. Observations on the nutrient foramina of the human radius and ulna. Anat. Rec., 134:685-97, 1959.

Sigma-Aldrich. Syringe Needle Gauge Chart. Sigma-Aldrich Chemicals Technical Library, 2017.

Trueta, J. \& Harrison, M. H. The normal vascular anatomy of the femoral head in adult man. J. Bone Joint Surg. Br., 35-B(3):442-61, 1953.

Trueta, J. \& Morgan, J. D. The vascular contribution to osteogenesis. I. Studies by the injection method. J. Bone Joint Surg. Br., 42-B:97-109, 1960
Corresponding author:

Lanka Ranaweera

Department of Anatomy

Faculty of Medicine

University of Kelaniya

11010, Ragama

SRI LANKA

Email: lanka@kln.ac.lk

Received: 18-02-2020

Accepted: 09-04-2020 